DOI:

Юлія Стасюк, викладач диригування Луцฺького педагогічного коледжу

\title{
МИСТЕЦЬКА РЕФЛЕКСІЯ КОНЦЕРТНОЇ ДІЯЛЬНОСТІ КИЇВСЬКОГО КАМЕРНОГО ХОРУ ІМ. Б. ЛЯТОШИНСЬКОГО ЯК СКЛАДОВОЇ СТАНОВЛЕННЯ ХОРОВОГО ВИКОНАВСТВА УКРАЇНИ ДРУГОЇ ПОЛОВИНИ ХХ СТОЛІТТЯ
}

У статті висвітлено творчу діяльність Київського камерного хору другої половини ХХст. Досліджено репертуарний пласт, щу вміщав в себе старовинну, класичну та сучасну музику, та здійснював суттєвий вплив на музичне життя столиці. Виявлено, щуо репертуарним акцентом у діяльності хорового колективу стала творча співпрачя та виконання високохудожніх творів композитора Б. Лятошинського, популяризація його хорової спадщини.

Розглянуто участь хорового колективу в культурно-концертному житті Києва і вагомий внесок у розвиток хорового виконавства в Украӥні та за ї межами.

Ключові слова: камерний хор; хормейстер; хорове мистецтво; виступ; концерт.

Jim. 8.

Yuliya Stasyuk, Lecturer of Conducting of Lutsk Pedagogical College

\section{THE ARTISTIC REFLECTION OFTHE CONCERT ACTIVITY OFTHE KYIV LYATOSHYNSKIY CHAMBER CHOIR AS A PART OFTHE FORMATION OFTHE UKRAINIAN CHORAL MUSIC IN THE SECOND HALF OF THE XX CENTURY}

An academic choral performance after the Great Patriotic War was regenerated extremely slowly, but we consider the second half of the twentieth century as the time of national-cultural revival of Ukraine. The development of the choral genre in Ukraine was facilitated during the Soviet era by the appearence of numerous amateur choirs in the schools, clubs, houses of culture, ensembles of songs and dances, amateur chapels of various casts. The musical life of the capital was always famous for the active work of numerous choir groups which created the artistic "face" of Kyiv, contributed to the spiritual elevation of its inhabitants.

Among a number of choral ensembles in Kyiv, a chamber choir under the direction of V. Ikonnik is distinguished by its activities and creative achievements. This team was the successor of the choral school traditions, renewed the acapella techniques and assisted the revival of academic choral performance of the second half of the twentieth century. Kyiv Chamber Choir named after. B. Lyatoshynskiy during his lifetime existence has achieved significant success and enriched the artistic life of the capital.

The team toured to the cities of Ukraine, as well as Poland, Yugoslavia, Czechoslovakia, to the republics of the Soviet Union: Belarus, Moldova, Kazakhstan and to Moscow. The choir often performed the works of those composers whose homeland its concerts passed on, that was pleasantly surprising to the public. The peculiarity of all concert programs was the performing of Ukrainian song arrangements, in particular M. Kolesi, K. Stetsenko, M. Leontovych and V. Ikonnik himself.

The choirmaster Viktor Ikonnik was a brilliant interpreter of the Ukrainian folk song and a propagandist of the works of Ukrainian composers.

The main place in the choir creative activity was the concerts devoted to the memory of outstanding figures: T. Shevchenko, M. Hogol; K. Stetsenko, G. Verovka, M. D. Leontovych, B. M. Lyatoshynskiy, D. Bortnyanskiy, S. Koday, G. Shyutz, J. Bach, G. Handel, D. Scarlatti. The first reading of the partsong concert of M. Diletskiy "Resurrection canon" (the decryption by N. Herasymova-Persidskaya) belongs to the choir.

The recordings of many works are made, among them there is the whole inheritance of K. Stetsenko, B. Lyatoshynskiy, choral concerts by M. Diletskiy, D. Bortnyanskiy, A. Vedel. A total amount is 25 discs.

In perspective, we plan to explore the concert activity of the Ensemble of Classical Music named by B. Lyatoshynskiy, which was reorganized into the Kyiv Lyatoshynskiy Chamber Choir.

Keywords: chamber choir; a choirmaster; choir art; a performance; a concert.

П остановка проблеми. Музичне життя столиці завжди славилося активною діяльністю численних хорових колективів, які творили мистецьке “обличчя” Києва, сприяли духовному піднесенню його мешканців. Серед низки хорових колективів Києва своєю діяльністю та творчими здобутками вирізняється камерний хор під керівництвом
В. Іконника. Цей колектив, паралельно національною заслуженою академічною капелою України “Думка”, заслуженою капелою України "Трембіта" та Чоловічою хоровою капелою України ім. Л.М. Ревуцького був продовжувачем традицій хорової школи, поновлювачем акапельної техніки та сприяв відродженню академічного хорового виконавства другої половини ХХ ст. 


\section{МИСТЕЦЬКА РЕФЛЕКСІЯ КОНЦЕРТНОЇ ДІЯЛЬНОСТІ КИЇВСЬКОГО КАМЕРНОГО ХОРУ ІМ. Б. ЛЯТОШИНСЫКОГО ЯК СКЛАДОВОЇ СТАНОВЛЕННЯ ХОРОВОГО ВИКОНАВСТВА УКРАЇНИ ДРУГОЇ ПОЛОВИНИ ХХ СТОЛІТТЯ}

Спираючись в основному на публікації в журналах “Музика” та щоденник концертної діяльності, що знаходиться в Національному будинку органної та камерної музики (м. Київ), нами здійснено спробу дослідити концертну діяльність хору ім. Б. Лятошинського в період з 1974 по 1981 рр., довести вагомість його внеску в розвиток хорового мистецтва України. Про цей колектив 3'явилася низка статей, наукових та періодичних видань, зокрема М. Гордійчука [1;2], А. Лащенка [4; 5], Г. Степанченко [6; 7], Л. Хіврич [8].

Метою статті $€$ висвітлення концертної (творчої) діяльності Київського камерного хору та його внесок у розвиток хорового виконавства Києва, України та за її межами.

Виклад основного матеріалу. Віктор Михайлович Іконник, учень заслуженого діяча мистецтв УРСР, професора К. Пігрова, після навчання в Одесі опинився у вирі мистецького життя Києва. У творчій атмосфері його авторитет як ерудованого фахівця невпинно зростав. Користуючись нагодою, у 1964 р. Віктор Михайлович створив аматорський хоровий колектив і дебютував 3 ним у ролі диригента.

Слава про колектив розійшлась у столиці 3 перших днів його створення. За спогадами одного 3 хористів, який на той час був студентом Київської консерваторіїВ. Скоромного ${ }^{1}$, репетиції аматорського хору користувалися великою популярністю серед студентів та молоді. Нове, незвичне академічне звучання приваблювало, новизна прийомів дивувала. На репетиціях переважала творча атмосфера та “залізна" дисципліна. Музикантів, що приходили на прослуховування та репетиції, було безліч - усі хотіли отримати місце у незвичайному камерному хорі, але туди брали тільки професіоналів, що могли виконувати надскладні твори з листа, та людей дисциплінованих, відданих хоровому мистецтву так, як і його хормейстер.

Завдяки новітній методиці хор уже в перший рік створення виступав із концертами та завоював визнання музикантів і численних любителів хорового співу. Найперше слухачів приваблював активний творчий пошук колективу, сміливе звернення до старовинної, класичної і сучасної музики та досконале виконавство.

У той час репертуар хорових колективів складався переважно зі світської музики радянського змісту, а камерний хор був пропагандистом сучасної української хорової музики, одним із небагатьох хорових колективів, що активно і без остраху виконував духовну

${ }^{1}$ Зі спогадів В. Скоромного, записаних автором статті. музику та твори українських сучасних композиторів та композиторів-класиків.

Високохудожній рівень виконання хорових творів та повна віддача себе мистецтву призводить до того, що В. Іконник став помітною постаттю у столиці, а виконавська майстерність любительського хору наповнювала концертні зали поціновувачами академічного мистецтва.

Київський камерний хор від початку свого існування виконував хорові твори, що є гордістю української культури. Найвагоміший пласт у виконанні хору представлений цінними художніми надбаннями українських композиторів-класиків Б. Лятошинського, О. Кошиця, К. Стеценка, М. Леонтовича та ін. Хор виконував духовні концерти М. Дилецького, М. Березовського, Д. Бортнянського, А. Веделя, твори М. Леонтовича, Б. Лятошинського, К. Стеценка. Велика увага відводилась виконанню композиторського доробку сучасних митців, таких як В. Гембера, Л. Дичко, В. Кирейко, Г. Майборода, В. Торміс, Р. Щедрін, М. Колесса.

Різноманітний та складний класичний репертуар виконувався в нашій країні вперше, що було надто сміливо - такий спів вражав і захоплював слухачів. Віктор Іконник як хормейстер вважав, що слухачів і хористів потрібно виховувати як творами української класики, так і високими зразками світової музики. Диригент працював над виконанням кращих творів та вдосконалював майстерність колективу 3 року в рік. Критики відзначали, що кожен наступний виконаний твір - це нова сходинка до вершини художньої досконалості.

Першорядне місце в концертній діяльності камерного хоруналежить творам Б. Лятошинського. Знайомство, дружба та творча співпраця між хором, його керівником та композитором Борисом Лятошинським принесла взаємну славу. Характерною рисою виступів було те, що майже усі концертні програми включали твори композитора, які В. Іконник вважав взірцевими. Борис Миколайович постійно був присутній на виступах, репетиціях, ювілеях хору і не раз визнавав, що саме цей колектив міг найкраще передати всі його задуми щодо гармонійного поєднання музичного та поетичного текстів [3, 141].

Потрібно зауважити, що виконання творів Б. Лятошинського - це показник високої виконавської майстерності. На теренах України немає жодного колективу, який би виконував більшість хорових творів Б. Лятошинського, окрім Київського камерного. Таким чином, В. Іконник був ще й активним популяризатором творчості свого сучасника. 


\section{МИСТЕЦЬКАРЕФЛЕКСІЯ КОНЦЕРТНОЇ ДІЯЛЬНОСТІ КИЇВСЬКОГО КАМЕРНОГО ХОРУ ІМ. Б. ЛЯТОШИНСЬКОГО ЯК СКЛАДОВОЇСТАНОВЛЕННЯ ХОРОВОГО ВИКОНАВСТВА УКРАЇНИ ДРУГОї ПОЛОВИНИ ХХ СТОЛІТТЯ}

Хор під керівництвом талановитого хормейстера жив активним творчим життям у столиці, їздив всією Україною та гастролював за кордоном. Кожен новий рік діяльності хору засвідчував новий рівень мистецької праці В. Іконника в осягненні професійного співу. 31973 р. аматорський хор офіційно став професійним колективом та змінив назву на Київський камерний, а у 1981 році йому присвоїли ім'я Б. Лятошинського.

Одним з цікавих мистецьких явищ концертного сезону $1973 / 74$ років у Києві став виступ новоутвореного хору. Концерт став першою репрезентацією молодого колективу перед широкою аудиторією. Перед вимогливими слухачами виступив уже сформований художній ансамбль, члени якого свідомі відповідальності за доручену справу, безмежно віддані своєму покликанню. Другий відділ концерту було присвячено творам українських авторів. Вперше прозвучали два хори А. Штогаренка на сл. А. Ісаакяна "Вітчизно-джан” і "Рідній країні” з циклу “Дружба народів”; вперше було виконано “Триптих" молодого українського композитора В. Бібіка. Значний інтерес викликало включення до програми концерту камерної кантати “Чотири пори року” Лесі Дичко для мішаного хору a'cappella в 9 частинах. Солісти: Л. Забіляста, Л. Лопушко, М. Турянін, О. Мартиненко, В. Буймістер. Програма концерту виявилася складною, та всі номери хор виконав майстерно, злагоджено ансамблево, інтонаційно чисто $[2,251]$.

1974 рік у творчому житті хору позначений новими мистецькими здобутками. Початок року ознаменував великий зведений концерт (13 січня) в Колонній залі ім. М. Лисенка, присвячений творчості Д.С. Бортнянського, де прозвучав хоровий концерт № 32. Вступне слово тримав доктор мистецтвознавства М. Гордійчук, який сказав, що спів хору в черговий раз засвідчив слухачам високу виконавську майстерність та професіоналізм.

А 29 січня того ж року в Київській державній філармонії відбувся концерт творів українських композиторів, приурочений до VI з'їзду композиторів України. У виконанні камерного хору прозвучали твори Б. Лятошинського на сл. М. Рильського й А. Фета та кантата “Пори року” Лесі Дичко, слова народні та ін. Серед безлічі концертних турів, наступним великим творчим етапом у діяльності хору стала участь у концерті V з'їзду Спілки композиторів СРСР, який

\footnotetext{
2 Зі щоденника гастрольної діяльності, що зберігається в будинку органної музики.

${ }^{3} 3 і$ щоденника гастрольної діяльності, що зберігається в будинку органної музики.
}

відбувся в Малому залі Московської державної консерваторії ім. П. І. Чайковського 1 квітня 1974 року. У концерті була виконана програма, подана вище, що засвідчує високий професіоналізм хору та сміливу українську політику та безумовно справила яскраве враження на публіку.

Концертний виступ хору 22 травня 1975 року, присвячений 30-річчю Перемоги радянського народу у Великій Вітчизняній війні мав два відділення. У першому прозвучали хорові твори українських композиторів Ю. Іщенка, Л. Дичко, обробки народних пісень М. Колесси, у другому - Б. Лятошинського, А. Шенберга та вперше виконали “П'ять хорів" за романом Ю. Бондарева “Гарячий сніг” В. Бібіка.

Наприкінці 1975 р., з 26 листопада по 30 грудня, відбулася серія гастролей по містах України: Луцьк, Рівне, Тернопіль, Хмельницький, Вінниця, Черкаси, Кіровоград, Полтава, Одеса (загалом 26 концертів) під час яких звучали хорові твори українських композиторів ${ }^{2}$.

Надзвичайно важливою подією в мистецькому житті столиці став концерт, присвячений 100 річчю від дня народження М. Леонтовича 12 грудня 1977 р. що відбувся в театрі опери та балету ім. Т. Шевченка. Окрім камерного хору, учасниками зведеного концерту були й інші колективи: хор студентів Київської консерваторії, Київська чоловіча хорова капела, Український народний хор ім. Г. Верьовки, капела “Думка", Державний театр опери та балету ім. Т. Шевченка, в постановці якого прозвучала одноактна опера “Русалчині Луки". У програмі концерту звучали обробки народних пісень композитора.

28 серпня 1978 р. в тому ж театрі відбувся концерт, присвячений 150-літтю від дня народження Л. Толстого. Хор вперше виконав твір В. Іконника на сл. М. Рильського “Ясна поляна”.

1979 р. 34 по 14 лютого у Москві хор виступив на звіті діячів мистецтв УРСР. Святковий концерт майстрів мистецтв і художніх колективів УРСР відбувся 7 лютого в Державному академічному Великому театрі СРСР. Виконана "Венеціанська ніч” М. Глінки та “А вже весна" М. Лисенка. Разом 3 камерним хором (керівник - заслужений діяч мистецтв В. Іконник) цю програму виконували заслужена академічна капела УРСР “Думка” (керівник - народний артист УРСР М. Кречко), Київська чоловіча хорова капела ім. Л. Ревуцького (художній керівник Є. Савчук). Диригент народний артист УРСР М. Кречко 3 .

5 квітня 1980 р. музична громадськість України святкувала 85-ліття від дня народження Бориса 


\section{МИСТЕЦЬКАРЕФЛЕКСІЯ КОНЦЕРТНОӤ ДІЯЛЬНОСТІ КИЇВСЬКОГО КАМЕРНОГО ХОРУ ІМ. Б. ЛЯТОШИНСЬКОГО ЯК СКЛАДОВОЇ СТАНОВЛЕННЯ ХОРОВОГО ВИКОНАВСТВА УКРАЇНИ ДРУГОї ПОЛОВИНИ ХХ СТОЛІТТЯ}

Миколайовича Лятошинського. Київський хор виступив 3 великою концертною програмою 3 творів композитора на сцені Київської державної філармонії. У І відділ увійшли твори композитора на слова М. Рильського, В. Бичка, А. Софронова, А. Фета, О. Пушкіна (усього 14 творів); II відділ складався з обробок народних пісень (14 творів) ${ }^{4}$.

319 липня по 3 серпня хор був активним учасником культурної програми “Олімпіада-80", яка проходила в Києві. 3 незмінним успіхом колектив виступав із сольними концертами на багатьох майданчиках столиці, а також у державній філармонії.

У програмутворчих виступів увійшли концерти присвячені творчості українських композиторів та приурочені до ювілеїв. Так, 14 жовтня 1981 р. в Республіканському будинку органної і камерної музики відбувся концерт 3 циклу “Творчі портрети”. Програма концерту складалася 3 творів Бориса Лятошинського на сл. Т. Шевченка, М. Рильського, А. Фета, О. Пушкіна, І. Буніна, Ф. Тютчева.

У концерті, присвяченому пам'яті Т. Г. Шевченка, що відбувся 18 березня того ж року, у I відділі були виконані твори 3 “Шевченкініани" на муз. А. Штогаренка, а саме “І будуть люди на землі”, “На вгороді коло броду”, “Караюсь, мучуся,... але не каюсь”, “Гімн Черничий”, “Ой одна я, одна”, “Я не нездужаю”. Окрім цього, “Шевченко” на сл. М. Рильського, муз. В. Кирейко; “Тече вода 3-під явора" на сл. Т. Шевченка, муз. Г. Гембера; “Сонце заходить" на сл. Т. Шевченка, муз. В. Іконника та твори на музику Б. Лятошинського "Серце Кобзаря" на сл. В. Бичка, "Чернеча гора" на сл. Є. Фоміна, на сл. Т. Шевченка "Тече вода в синє море", "Із-за гаю сонце сходить", "Над Дніпровою сагою”, “У перетику ходила”.

У святкуванні 1500-річчя міста-героя Києва (1981 р.) камерний хор відзначився цікавими концертними програмами, які слухали любителі і гості в музеї “Андріївська церква” (пам’ятка архітектури XVIII ст.) та в залі Київської державної філармонії. У програмі прозвучали твори Д. Бортнянського, М. Березовського, А. Веделя, М. Дилецького; українських композиторів - Б. Лятошинського, Л. Дичко, обробки народних пісень М. Леонтовича, Я. Степового, К. Стеценка (та оригінальні твори), М. Колесси, Т. Сидоренко-Малюкової (усього 34 твори).

Концертні заходи, присвячені 100-річчю від дня народження К. Г. Стеценка відбулись у травні та

${ }^{4} 3$ і щоденника гастрольної діяльності, що зберігається в будинку органної музики. червні в Київській державній філармонії та музеї Т. Г. Шевченка, де були виконані твори автора: "Радійте, співайте!" та "Усе жило, усе цвіло" на сл. О. Олеся, “Сон” на вірші П. Грабовського й українські народні пісні в обробці К. Стеценка “3під гір, з-під долин”, “Павочка ходить”.

21 вересня 1981 року на батьківщині К. Г. Стеценка в селі Квітки на Черкащині відбулося відкриття Всесоюзного фестивалю “Золота осінь”. На честь 100-річчя від дня народження хор виконав концерт, що складався 3 творів композитора.

11 жовтня Спілка композиторів України у концертному залі влаштувала авторський вечір композитора А. Штогаренка, професора, народного артиста СРСР, лауреата державної премії СРСР та державної премії УРСР ім. Т. Г. Шевченка присвячений 80-літтю 3 дня народження, у якому камерний хор узяв активну участь.

Про любов публіки свідчить той факт, що концерти хорузавжди відбувалися при наповнених залах і закінчувалися численними подяками, нагородами, відгуками й рецензіями в пресі.

У 1981 р. колектив відзначив своє десятиліття. За ці роки хор набув професійності, артисти стали майстрами виконавського мистецтва. Жодна музична подія в країні не обходилась без участі колективу, він знаний і за кордоном. Важливою подією цього року стало присвоєння камерному хору імені видатного композитора, педагога і друга Бориса Миколайовича Лятошинського, а Віктору Іконнику наступного року присвоїли звання лауреата Державної премії УРСР ім. Т. Г. Шевченка "За популяризацію хорової спадщини Б. Лятошинського і концертновиконавську діяльність останніх років".

За високі досягнення у творчій діяльності хор був нагороджений такими державними відзнаками: грамота Миколаївського обласного відділення музично-хорового товариства УРСР від 5 листопада 1974 р. за високу виконавську майстерність, і за істотний внесок в розвиток радянської хорової культури, почесна грамота Президії Верховної Ради Української УРСР від 27.05.1977 р. як учасників Всесоюзного фестивалю мистецтв “Київська весна", почесна грамота Президії Верховної Ради РСФСР від 9.11.1979 р. за активну участь в міроприємствах, присвячених святкуванню 325-ліття возз'єднання України з Росією, на всесоюзному огляді роботи концертних організацій і художніх колективів 3 творчою молоддю, в вересні 1983 р. Київському камерному хору присуджується диплом II ступеня 


\section{МИСТЕЦЫКАРЕФЛЕКСІЯ КОНЦЕРТНОЇ ДІЯЛЬНОСТІ КИЇВСЬКОГО КАМЕРНОГО ХОРУ ІМ. Б. ЛЯТОШИНСЬКОГО ЯК СКЛАДОВОЇ СТАНОВЛЕННЯ ХОРОВОГО ВИКОНАВСТВА УКРАЇНИ ДРУГОЇ ПОЛОВИНИ ХХ СТОЛІТТЯ}

(за досягнуті успіхи в ідейно-політичному та професійному вихованні творчої молоді).

У травні 1992 р. Київський камерний хор з'єднався $з$ новоствореним камерним оркестром і був утворений Ансамбль класичної музики імені Бориса Лятошинського [8].

Висновки.Київський камерний хор ім. Б. Лятошинського за час свого існування досягнув значних успіхів і збагатив мистецьке життя столиці. Колектив гастролював містами України, а також у Польщі, Югославії, Чехословаччині, в республіках Радянського Союзу: Білорусії, Молдові, Казахстані та в Москві. Часто хор виконував твори тих композиторів, на чиїй батьківщині проходили його концерти, чим приємно дивував публіку.

Особливістю всіх концертних програм було виконання обробок українських пісень, зокрема М. Колесси, К. Стеценка, М. Леонтовича та самого В. Іконника. Хормейстер Віктор Іконник був блискучим інтерпретатором української народної пісні та пропагандистом творів українських композиторів.

Чільне місце у творчій діяльності хору займали концерти, присвячені пам'яті видатних постатей: Т. Шевченка, М. Гоголя; К. Стеценка, Г. Верьовки, М. Д. Леонтовича, Б. М. Лятошинського, Д. Бортнянського, 3. Кодая, Г. Шютца, Й. Баха, Г. Генделя, Д. Скарлатті. Хору належить перше прочитання партесного концерту М. Дилецького “Воскресенський канон” (розшифровка Н. Герасимової-Персидської). Здійснені записи багатьох творів, у числі яких уся спадщина К. Стеценка, Б. Лятошинського, хорові концерти М. Дилецького, Д. Бортнянського, А. Веделя. Усього 25 платівок.

У перспективі плануємо дослідити концертну діяльність Ансамблю класичної музики ім. Б. Лятошинського, у який було реорганізовано Київський камерний хор ім. Б. Лятошинського.

\section{ЛІТЕРАТУРА}

1. Гордійчук М. Диригує Віктор Іконник / М. Гордійчук. - К.: Музична Україна. - 1979. № 86 . - C. 12 .

2. ГордійчукМ.Народження камерного/М. Гордійчук. // Музика і час. - 1984. - С. 251.
3. Иконник В. Творческое общение с Б.М.Лятошинським / В. Иконник// Лятошинський Б. Н. Воспоминания. Письма. Материалы: В 2-х ч. Сост.: Л. Н. Грисенко, Н. И. Матусевич. - К.: Музична Україна, 1985. - Ч. І. Воспоминания. C. 141 .

4. Лащенко А. 3 історії Київської хорової школи / А. Лащенко. - К.: Музична Україна, 2007. - С. 170.

5. Лащенко А. Хорові мініатюри / А. Лащенко // Музика. - № 5. Вересень-Жовтень. - 1982. C. 32 .

6. Степанченко Г. Ансамбль класичної музики імені Бориса Лятошинського / Г. Степанченко. K., 2004.

7. Степанченко Г. Самовіддане служіння музиці / Г. Степанченко // Музика. - № 3. - 2005. - C. 18-19.

8. Хіврич Л. Духовність - краси основа / Л. Хіврич // Музика. - № 6. - 1989. - С. 14-18.

\section{REFERENCES}

1. Hordiychuk, M. (1984). Dyryhuye Viktor Ikonnyk [Conducted by Viktor Ikonnik]. Musical Ukraine. Kyiv, no. 86, p. 12. [in Ukrainian].

2. Hordiychuk, M. (1984). Narodzhennia kamernoho [Birth of chamber]. Music and Time. Kyiv, p. 251. [in Ukrainian].

3. Ikonnyk, V. (1985). Tvorcheskoe obshchenie s B. M. Liatoshynskym [Creative communication with B. M. Liatoshynskiy]. Lyatoshynskiy B. N. Vospomynaniia. Letters. Part I: Memories. Musical Ukraine. Kyiv, p.141. [in Russian].

4. Lashchenko, A. (2007). Z istorii Kyivskoii khorovoii shkoly [From the history of the Kyiv Choir School]. Musical Ukraine. Kyiv, p.170. [in Ukrainian].

5. Lashchenko, A. (1982). Khorovi miniatiury [Choral miniatures]. Music, no 5,p. 32. [in Ukrainian].

6. Stepanchenko, H. (2004). Ansambl klasychnoii muzyky imeni Borysa Lyatoshynskoho [The ensemble of classical music named after Boris Lyatoshynsky]. Kyiv. [in Ukrainian].

7. Stepanchenko, H. (2005). Samoviddane sluzhinnia muzytsi [Dedication to music]. Music, no. 3, pp. 18-19. [in Ukrainian].

8. Khivrych, L. (1989). Dukhovnist - krasy osnova [Spirituality is the basis of beauty]. Music, no. 6, pp. 14-18. [in Ukrainian].

Стаття надійшла до редакщії 10.05.2018

G58080

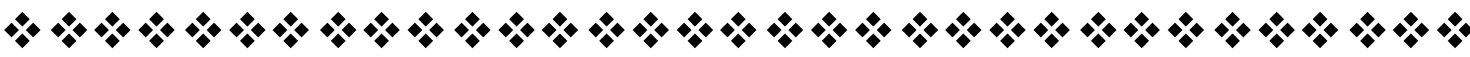

